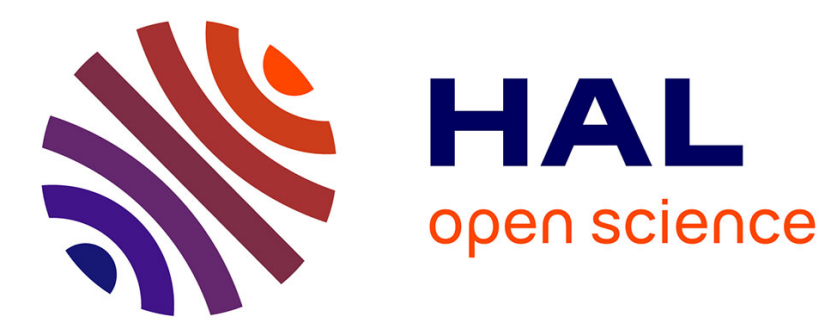

\title{
Globalization and Competitive Strategies in European Vulnerable Regions
}

\author{
Antonio Affuso, Roberta Capello, Ugo Fratesi
}

\section{To cite this version:}

Antonio Affuso, Roberta Capello, Ugo Fratesi. Globalization and Competitive Strategies in European Vulnerable Regions. Regional Studies, 2010, pp.1. 10.1080/00343401003614290 . hal-00608024

\section{HAL Id: hal-00608024 \\ https://hal.science/hal-00608024}

Submitted on 12 Jul 2011

HAL is a multi-disciplinary open access archive for the deposit and dissemination of scientific research documents, whether they are published or not. The documents may come from teaching and research institutions in France or abroad, or from public or private research centers.
L'archive ouverte pluridisciplinaire HAL, est destinée au dépôt et à la diffusion de documents scientifiques de niveau recherche, publiés ou non, émanant des établissements d'enseignement et de recherche français ou étrangers, des laboratoires publics ou privés. 


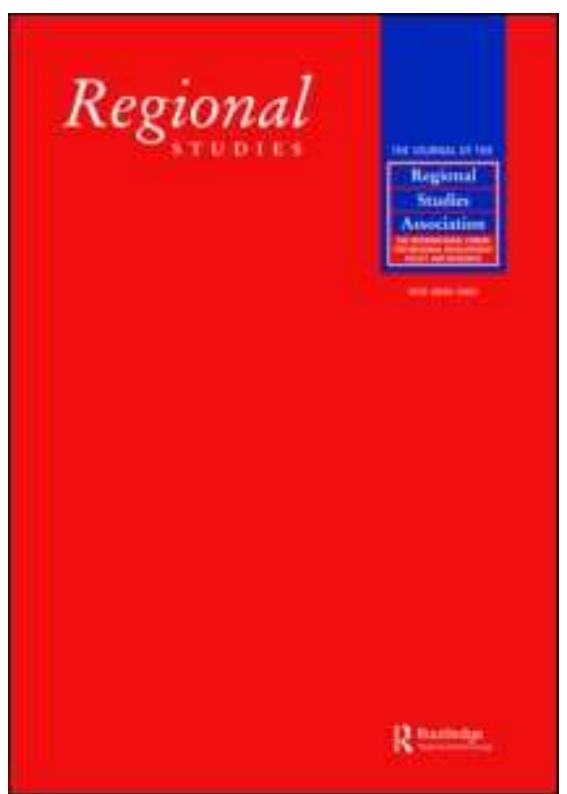

\section{Globalization and Competitive Strategies in European Vulnerable Regions}

\begin{tabular}{|r|l|}
\hline Journal: & Regional Studies \\
\hline Manuscript ID: & CRES-2009-0038.R3 \\
\hline Manuscript Type: & Main Section \\
\hline JEL codes: & $\begin{array}{l}\text { R10 - General < R1 - General Regional Economics < R - Urban, } \\
\text { Rural, and Regional Economics, R11 - Regional Economic Activity: } \\
\text { Growth, Development, and Changes < R1 - General Regional } \\
\text { Economics < R - Urban, Rural, and Regional Economics }\end{array}$ \\
\hline Keywords: & $\begin{array}{l}\text { globalization, regional growth, European vulnerable regions, } \\
\text { regional reconversion }\end{array}$ \\
\hline
\end{tabular}

\section{scholarONE" \\ Manuscript Central}


Globalization and Competitive Strategies in European Vulnerable Regions

\author{
Antonio Affuso*, Roberta Capello**, and Ugo Fratesi*** \\ * Department of Building, Environment, Sciences and Technology, Politecnico di Milano. \\ Email:antonio.affuso@polimi.it. \\ **Department of Building, Environment, Sciences and Technology, Politecnico di Milano. \\ Email: roberta.capello@polimi.it \\ ***Department of Building, Environment, Sciences and Technology, Politecnico di Milano. \\ Email:ugo.fratesi@polimi.it
}

(Received February 2009: in revised form November 2009) 


\begin{abstract}
The paper highlights the role played by structural economic features and by industrial competitive strategies in the performance of a group of European regions, defined as 'vulnerable' because of their specialisation in industries particularly exposed to international trade.

Different growth patterns emerge among them. The most successful regions are those with a strong presence of high value added functions, of best-performing vulnerable sectors, but also with high structural funds expenditure on human resources. Moreover, among the industrial strategies analysed, it is found that the only winning strategy explaining higher productivity gains is industrial reconversion at the expense of employment growth.
\end{abstract}

Key words: globalization, European vulnerable regions, regional growth

JEL: R10, R11 
1. Globalization and Industrial Competitive Strategies

Globalization processes have increased their scope and magnitude over the last ten years. Emerging economies have placed the competitiveness of the European economy under severe strain; and the way in which the advantages and disadvantages of greater economic and market integration are distributed is not homogeneous over space.

Regional economies, in fact, differ in terms of their "vulnerability" to international trade integration. The most vulnerable regions are those that are specialised in industries particularly exposed to international trade. Within this group of regions we expect to find completely different growth patterns, reflecting the different pro-active and re-active strategies that regions can put in place as well as the way in which they are inserted in global value chains (HUMPREY and SCHMIDZ, 2002).

Although manufacturing industries are threatened by changes in trade patterns and multinational location decisions, they can still find favourable contexts for subsistence and development in advanced and EU countries provided that they renew their industrial and territorial strategies.1 A recent OECD Report shows how the supposed de-industrialization process is often only the result of industrial restructuring and productivity increase more than being the effect of trade challenges: ten of the eleven top manufacturing countries in the world are developed countries, and five belong to EU-15 (Germany, France, UK, Italy and Spain) (OECD, 2007).

Regions - conceived as collective agents implicitly or explicitly defining specific development trajectories - compete in the global economy by building on their historical strengths and identifying opportunities for diversification and enlargement of their specialisations by strengthening their know-how and knowledge base (CAMAGNI, 2001, 2002). Regional 
comparative advantage vis-à-vis external competition is therefore made dependent, among other things, on three, non-mutually exclusive, industrial competitive strategies, namely:

1 - increasing productivity in the same sectors of specialization. This can be achieved by means of new technologies, organizational and managerial innovation, or, in some cases, corporate adaptation, especially vertical (with suppliers and customers - ABRAHAM K. G. and TAYLOR S. K. (1996)) and horizontal (with similar firms in order to achieve economies of scale) integration. This strategy protects and supports employment growth, and for this reason we label it a strategy of 'raising productivity through innovation in the same sector';

2 - reconversion of regions to higher phases of the production process, i.e. in a world where production is increasingly disintegrated (FEENSTRA, 1998; FONTAGNÉ and LORENZI, 2005 ; BALDWIN, 2006), decentralizing the low-level production phases to areas with lower wages and production costs. This strategy preserves the regional specialization (especially in terms of value added), generally at the expenses of job losses. Most times this is a cost-cutting strategy, but it might also involve functional change within the sector, for example through product development. In the impossibility to distinguish emprically the two cases, we label this a strategy of 'cutting costs by changing to higher value segments';

3 - reconversion of the regional sectoral structure from low value added sectors to high value added ones, leaving the production of the sectors most affected by competition to the competitors newly arrived from other countries. This can take place either at the expense of job losses (cutting costs by changing sectors) or by increasing jobs (raising productivity by moving to higher value added sectors), the final objective being to find the best position in the territorial division of labour (DUNFORD, 2003). 


\begin{abstract}
If none of the three strategies is implemented, regions can remain competitive only by adopting very traditional strategies to limit production costs through either wage or employment decreases, the latter achieved by means of firm closures.
\end{abstract}

Our aim in this paper is to highlight the economic performance of a particular group of regions identified on the basis of their specialisation in an industry which records openness to international competition above the European average, ${ }^{2}$ and the role that the above-mentioned industrial competitive strategies can play in the growth patterns of European regions. In particular, we intend to measure the degree of success of industrial competitive strategies for vulnerable regions, which are defined here as those regions specialised in sectors that are particularly open to global trade. In terms of sectoral decomposition, we are interested only in manufacturing industries, which have been historically affected firstly and mostly by globalisation processes. The empirical exercise is useful for drawing some policy lessons on successful regional strategies.

The structure of the paper is as follows. Section 2 describes the growth patterns of vulnerable regions from 1995 to 2005 , while section 3 presents the structural features associated with the different growth patterns. Section 4 highlights the most important success factors of vulnerable regions, among which measurement is made of the role of renewed industrial competitive strategies.

\title{
2. Growth Patterns of European Vulnerable Regions
}

Figure 1 represents the European vulnerable regions at Nuts 2 level obtained from the analysis explained in Appendix 1. 
[INSERT FIGURE 1 HERE] 
Starting from the idea that productivity increases can take place within different structural processes which affect the general performance of the regional economies in rather different ways (CUADRADO et al., 2000; GARDINER et al., 2004; KAMARIANAKIS and LE GALLO, 2003) (CAMAGNI (1991) has suggested a statistical methodology with which to highlight whether productivity gains are the outcome of the growth of new and efficient firms, reconversion processes, the restructuring of existing production through process innovation, or the dropping out of nonefficient productions. In particular, CAMAGNI suggests a method to analyze two indicators simultaneously on a chart: relative employment growth, and relative productivity growth, calculated with the following formulas: ${ }^{3}$

$$
\begin{aligned}
& \left(\frac{\operatorname{Pr} o d_{r}^{2005}}{\operatorname{Pr} o d_{r}^{1995}}\right)^{1 / 10}-\left(\frac{\operatorname{Pr} o d_{E U}^{2005}}{\operatorname{Pr} o d_{E U}^{1995}}\right)^{1 / 10} \\
& \left(\frac{E m p_{r}^{2005}}{E m p_{r}^{1995}}\right)^{1 / 10}-\left(\frac{E m p_{E U}^{2005}}{E m p_{E U}^{1995}}\right)^{1 / 10}
\end{aligned}
$$

An interesting feature of this methodology is that, when these two indicators are plotted on two axes, a $45^{\circ}$ negatively sloped line passing through the origin approximates a condition of regional product growth equal to the national average. In fact, a region may develop at the same rate as the national GDP either if both productivity and employment grow at the same rate as the national 
average or if productivity increases at a lower rate but employment does so at a proportionally higher-than-average rate, and vice versa.

Six possible patterns of regional growth emerging from the chart may be described as follows (Fig. 2):

1. virtuous cycle, when higher-than-average productivity growth generates good performance in both employment and output;

2. restructuring, when higher-than-average productivity growth is achieved through drastic employment cuts, leading nevertheless to good output performance;

3. dropping out, when productivity growth is achieved by closing down inefficient production units, generating lower-than-average production growth;

4. de-industrialization, defined as a vicious cycle in which employment cuts are unable to restore competitiveness, a condition that perpetuates job losses and low output growth;

5. industrial conservatism, when poor productivity growth is accompanied (and sometimes explained) by better-than-average employment growth; this strategy is more likely to take place in the presence of public assistance and industrial rescues;

6. economic take-off, when lower-than-average productivity performance occurs together with very good employment performance, so that the effect on total value added is positive; this strategy is sometimes accompanied by explicit or implicit assistance policies which spur the initial development of the areas. 
[INSERT FIGURE 2 HERE]

We have applied the six patterns of growth methodology as described above to the vulnerable regions of Figure 1, calculating equations (1) and (2) with Eurostat data on regional (NUTS2) industry employment and industry value added over the period 1995-2005. The results (for 102 vulnerable regions) are plotted in Figure 2, where each region is placed in the position determined by its relative employment growth (horizontal axis) and its relative productivity growth (vertical axis).

Interestingly, there are vulnerable regions in each of the six patterns. However, only two of the six patterns can be considered positive for the regions. In fact, whilst de-industrialization is the worst situation, also the cases of dropping out and of industrial conservatism are negative: in the former case, an apparently good productivity performance is the result of the simple elimination of production units, with no or few positive counterparts; in the latter case, the good employment situation does not derive from endogenous regional development but rather from exogenous (somewhat artificial) intervention policies unlikely to induce a virtuous cycle in the medium and long run.

Often, the same artificial growth conditions apply to the case of economic take-off: the regions in this pattern achieve above-average performances in terms of employment and GDP growth, but this situation can change quite rapidly because it comes about in spite of productivity losses, so that it is hard to maintain in the absence of public assistance.

Consequently, the two patterns that are to be considered positive are the virtuous cycle and the restructuring one. The three reaction strategies are therefore successful if they are able to put vulnerable regions in these two quadrants. 
The six patterns of growth are not enough to identify a correspondence between regions and their strategies. In fact, the six patterns lack indications on how the employment and productivity performances are actually achieved; in particular, whether or not they are achieved by modifying the regional sectoral structure. Calculated for the 97 out of 102 vulnerable regions for which data were available, sectoral reconversion has been measured using the so-called Lawrence index:

$$
{ }^{1995-2002} S R C_{r}=\frac{1}{2} \sum_{j}\left|\frac{{ }^{2002} V A_{j}^{r}}{{ }^{2002} V A^{r}}-\frac{{ }^{1995} V A_{j}^{r}}{{ }^{1995} V A^{r}}\right|
$$

where $r$ is the region, $j$ are the manufacturing sectors at 1-digit level and the pre-multiplication by $1 / 2$ is necessary in order to ensure that the range of this measure is from 0 to 1.

Note that a high value on the Lawrence index may conceal at least the three following different behaviours: the first is the change of specialization due to classic reallocation from one sector to another; the second is a crisis concentrated in some sectors which heavily decreases their total value added so that their share decreases and the shares of the others increase as a consequence, despite little or no increase in total value added; the third is a boom concentrated in some sectors, which consequently increase their shares to the detriment of the shares of the other sectors, which however do not diminish in absolute terms.

Figure 2 sets out the results of the Lawrence index for each region by means of different symbols: squares if the region has modified its sectoral structure more than the average; triangles if the region has modified its sectoral structure less than the average.

The four possible alternatives suggested by the "sectoral change" indicator plotted in Figure 2 with the help of squares and triangles are not direct measures of industrial strategies, but in the absence 
of pervasive policies or statistical errors, they capture quite well the outcomes of industrial strategies. For this reason, Figure 2 can help us to identify which industrial strategy can be linked to each pattern of growth of vulnerable regions.

The first strategy - increasing productivity in the same sectors - is represented by triangle regions in the virtuous cycle quadrant (case 1 in Figure 2). There is only one region belonging to this category, namely Közép-Dunántúl in Hungary; this result can signal that this strategy is difficult to implement.

In a global competitive arena increasingly characterized by trading tasks (GROSSMAN and ROSSI-HANSBERG, 2008), the second strategy - i.e. reconversion of the regions to higher phases of the production process - involves job losses in the lower phases due for example to the externalization of these phases to countries with lower labour costs (case 2 in Figure 2). ${ }^{4}$ Also thanks to the externalization of low-skilled jobs and phases, however, domestic firms in the same sectors are able to thrive, and hence to increase their domestic productivity and value added. Moreover, they are normally able to increase the number of jobs in the higher phases and qualifications.

This strategy usually leads to a total employment loss, since the increase of jobs in the highest qualifications is smaller than the loss of jobs in the lowest ones. In far less common cases in which this strategy leads to employment increases, this situation is statistically indistinguishable from that of regions following the first strategy, and marked with triangles in quadrant I. Our distinction is made acceptable by the fact that, conceptually speaking, cases in which reconversion to higher phases of the production process increases employment at the same time are rare.

As expected, the strategy of reconversion to higher phases of the production process is most widely used in Western European regions, but also in some Eastern ones. Note that the strategy adopted by the - unsuccessful - triangle regions in the dropping-out quadrant is not very different from strategy 
2. However, triangle regions in the dropping-out quadrant adopt an externalization strategy with less success, so that domestic productivity increases but the job gains in higher phases are not enough, and total value added performance is relatively bad.

The third strategy - reconversion of the regional sectoral structure - extends across the two quadrants of virtuous cycle and restructuring. In fact, any restructuring involves a loss of jobs in the obsolete sectors; and the increase of jobs in the new, more productive, sectors may be insufficient to compensate for this loss. ${ }^{5}$

If the job gains in new sectors more than off-set the job losses in the lower phases, we have the case of squares in the virtuous cycle quadrants (case 3a in Figure 2). For these regions, the reconversion has been particularly successful and a large number of jobs in the new sectors have been created. Interestingly, these regions are mainly in Eastern Europe, with the addition of the two Irish ones and two Finnish ones ${ }^{6}$.

When the jobs created in the new and more productive sectors are not enough to compensate for the loss of jobs in the old sectors, the sectoral restructuring strategy involves a relatively high increase of GDP and value added, but a relatively low performance in employment (case $3 b$ in Figure 2). This is the case of squares regions in Figure 1, which are mainly Eastern European ones, but also some regions of Central European countries.

The regions pertaining to the six patterns, as well as the sectoral reallocation of vulnerable regions, are depicted in Figure 3, where it is evident that the various patterns characterize different areas of Europe. The virtuous-cycle pattern is exhibited by a small number of Eastern European regions and by two recently dynamic Western countries, namely Finland and Ireland. The restructuring pattern frequently occurs; but it is spatially concentrated, mainly in regions of central Europe, as well as in 
the Balkans and on the Baltic. The dropping out pattern is characteristic of many regions of Germany, plus a few others in the East. The de-industrialization pattern is typical of French, Italian and Belgian regions, some of which are strong regions which should be able to replace manufacturing with services. The industrial-conservatism pattern is typical of the Italian Adriatic coast, where the industrial district model (GIULIANI E., et al., 2005) may not be able to cope with the challenges of globalization without public support, plus the North of Portugal and Dél-Dunántúl in Hungary. Finally, the economic take-off pattern is most frequent in regions assisted with structural funds and located in Spain, Italy and Greece. It also includes the sparsely populated, and hence Objective 1, Finnish region of Pohjois-Suomi.

\section{[INSERT FIGURE 3 HERE]}

Also shown in Figure 3 are the strategies adopted by the vulnerable regions falling within the two winning quadrants. As already mentioned, only one vulnerable region falls within the virtuouscycle quadrant without sectoral restructuring (strategy 1), whereas all the others in this quadrant are able to achieve this by means of a successful sectoral reconversion strategy (strategy 3a). Most successful vulnerable regions are in the restructuring quadrant. They have adopted a strategy of either reconversion to higher phases of the production process (strategy 2) or of reconversion to higher value added sectors (strategy 3b). It is interesting that Strategy 2, reconversion to higher phases, with externalization of lower phases to other regions, is the one predominant in Western countries: Germany, Austria, Sweden and Greece, plus Slovenia. In Eastern countries, by contrast, 
more common is strategy $3 \mathrm{~b}$ of reconverting the sectoral structure from old low-value added sectors to new sectors with higher value added (BURDA et al., 1993; BALDWIN el al., 1997).

3. The Structural Features and Industrial Growth Patterns of European Vulnerable Regions

Observing the six different patterns of the European vulnerable regions is not yet enough to draw any economic consequences relevant to policy. By characterizing these six groups of regions, on the contrary, it will already be possible to say, inductively, something about the factors which enable the regions to pursue one of the three strategies successfully. The multivariate analysis of the causal relationships between the regional characteristics and economic performance will be left for Section 4. Presented now is a descriptive analysis which identifies the characteristics which fit the patterns.

We analyzed a broad set of characteristics, which horizontally pervade all sectors and are not confined to economic aspects but comprises social and settlement ones as well. Each quadrant in Figure 4 contains the list of structural features found to be statistically different between the group of regions belonging to that quadrant and all other vulnerable regions.

[INSERT FIGURE 4 HERE] 
Note that the characteristics presented in Figure 4 are not part of the definition of the six patterns of growth; they are simply the regional features that characterize the European vulnerable regions falling within each quadrant. The empirical associations of characteristics with patterns, however, will turn out to be reasonable.

Vulnerable regions associated with a virtuous cycle of development are characterized by the following features: the presence of high value added functions (large shares of corporate managers); the best performing vulnerable sectors, in particular the marked growth of the electric and electronics sector; and high expenditure of structural funds on social integration and human resources. Moreover, these regions act as the donors of growth, more than its receivers: in fact, they grow less if they are located near to growing regions.

A large share of science and technology and low expenditure on structural funds characterize regions exhibiting restructuring processes. Job losses are high, probably also caused by low structural funds expenditure, while innovation helps increase industrial productivity, which records a higher-than-average value added growth. The situation in which job losses and productivity increases are not sufficient to compensate for value added growth (dropping out) is typical of vulnerable regions achieving poor performance in the vulnerable sectors and having neighboring regions with a high market potential: these regions seem to grow because of the existence of a large market in neighboring regions.

Vulnerable regions suffering from deindustrialization - i.e. industrial employment crisis, industrial productivity losses and value added decreases - are associated with large shares of public employment and of managers in SMEs. Moreover, the growth of these regions is characterized by high positive spillovers of growth: their manufacturing growth seems to depend on their geographical proximity to growing regions. 
Both industrial conservatism and economic take-off of vulnerable regions are characterized by high structural fund expenditures and a large share of tertiary activities. This might be a signal that public financial support and the development of the service sector act more on industrial employment dynamics than on industrial productivity growth.

To exploit the potential of Figure 2, which simultaneously considers employment, value added and productivity increases, the spiders in Figure 5 are represented with the axes in the centre of each growth pattern quadrant rather than being evenly spaced. In this way, besides observing the differences among groups, we are also able to detect which variables have a positive or a negative effect, and on which of the three axes the effect is more evident. In particular, if the diagram of one variable is shifted upwards, this variable is associated with a positive effect on productivity; if the diagram is shifted rightwards, the association is with a positive effect on employment; if the diagram is shifted up-and-rightwards, the variable is associated with a positive effect on GVA.

As regards professions (Figure 5a), corporate managers are more frequent in the virtuous-cycle, restructuring and dropping out quadrants. For this reason, they appear to be associated with higherthan-average productivity growth. This is plausible, since they are a good proxy for the higher value added functions. By contrast, the managers of small enterprises are more frequent in the restructuring, dropping out and de-industrialization quadrants, which implies that they are mainly associated with low employment performance, since small enterprises are generally less able to meet the international challenges of globalization. ${ }^{7}$ Finally, lower-qualified office workers characterize the dropping out and de-industrialization patterns, i.e. regions which abandon the manufacturing sector in favour of the service sector. 
Figure $5 \mathrm{~b}$ evidences three structural economic variables. The first is the share of human resources in science and technology (HRST), which is especially large in the upper quadrants (and is hence associated with positive productivity performance) but also in de-industrialization regions, which may use their HRST endowment to move to the service sector. The share of self-employed workers without employees, which represents the amount of micro-entrepreneurial self-made initiatives, is highest in the quadrants of economic take-off and industrial conservatism, suggesting that these initiatives are able to create employment but not productivity and also have little effect on GVA: in the age of globalization, micro-firms appear to be a way to deal with unemployment rather than to produce development. The third variable is the share of the tertiary sector, which is rather homogeneous and hence does not appear to be a strong discriminant. However, it is stronger in the quadrants on the left, and is hence associated with de-industrialization and dropping out, which are easier for those regions where tertiary activities are more developed.

\section{[INSERT FIGURE 5 HERE]}

Figure $5 \mathrm{c}$ represents the growth spillovers (calculated with the distance-weighted and size-weighted GDP growth of neighboring regions) and income spillovers (calculated with the distance-weighted GDP of neighboring regions) on vulnerable regions. They appear to be much stronger in the deindustrialization and dropping-out quadrants. Hence, rather surprisingly, spillovers are not positively associated with manufacturing performance for European vulnerable regions. Various explanations are possible: first, the fact that many vulnerable regions in these two quadrants are located in central Europe, which tends to be more accessible; second, the fact that spillovers do not 
affect all types of regions in the same way; but they do so differently according to their settlement structure (CAPELLO, 2009); third, the possibility that, for vulnerable regions, their closeness to strong regions is not an advantage but a problem, since this may hamper the growth of manufacturing, which spills over to the stronger neighbors.

Finally, represented in Figure 5d are the effects of policy support: in particular, total Structural Funds expenditure 1994-99 and the sub-set of Structural Fund expenditure related to Social Integration and Human Resources (Objectives 1, 2, 3 and 6 ESF). All of them exhibit a similar pattern, stronger in the virtuous cycle quadrant but also in the economic take-off and industrial conservatism ones. For this reason, Structural Funds support seems to be positive for vulnerable regions, but has to be associated mainly with manufacturing employment growth, rather than with manufacturing productivity growth. ${ }^{8}$

\section{Industrial Competitive Strategies and Regional Performance}

\subsection{Competitive strategies and success factors}

The aim of this section is to highlight the role of the above-mentioned industrial competitive strategies in the performance of vulnerable regions. Indeed, vulnerable regions do not constitute a homogenous group, and different strategies imply different consequences on the economic performance and structure of regions.

Having no possibility to obtain any direct measure of the industrial competitive strategies, we adopt an indirect approach and approximate them with the presence in the area of "success factors" that can be potential outcomes of the strategies in the regions, namely: ${ }^{9}$ 
1. the degree of innovation, as an outcome of a strategy of productivity gains via innovation, measured in terms of share of employment in science and technology. This indicator is only partially a proxy for innovation, since it captures technological advances, which are more frequently achieved by large firms or by integrated ones. What this indicator does not capture are all organizational, managerial and process innovations, which are as important as technological ones for achieving productivity gains. Unfortunately, to our knowledge no other data are available on these kinds of innovation;

2. the composition of the labour force with a predominance of high value-added jobs, as a measure of the rationalization of low value added functions in favor of higher ones ${ }^{10}$;

3. the degree of sectoral reconversion, as an outcome of a reorganization strategy towards new sectors, measured by the Lawrence index.

In addition to these three proxies, we control for four types of structural factors most frequently cited by regional development theories as affecting regional economic performance, in particular the sectoral, geographical and settlement structure of a region, and European policies, namely:

- the degree of sectoral specialization; when specialization takes place in the most successful sectors, it becomes a driver of growth through multiplier effects on consumption and income generated by an increase in exports. In the same way, a specialization in non-dynamic sectors may lock a region into a vicious cycle of development (CAMAGNI, 1991). Regional specialization is expressed by the Herfindahl index;

- the relative geographical position vis-à-vis other regions; because regional economies are open economies, closely integrated with each other, their growth patterns depend on the dynamics of other regions. This is calculated as the growth of regions other than region $r$ discounted by the distance of each region from region $r$.

- the settlement structure of a region, which may conceal economies or diseconomies of agglomeration once a region is characterized by a high agglomeration structure. In order to 
take this factor into account, we use a dummy variable assuming value 1 if a region has a city with more than 300,000 inhabitants and with a population density of more than 300 inhabitants / km sq. or a population density of $150-300$ inhabitants / km sq.

- European policies sustaining regional growth, expressed by structural funds expenditures.

\begin{abstract}
All these factors were tested on vulnerable regions in regard to different performance indicators: in particular employment, value added, and productivity dynamics. Structural differences between vulnerable and non-vulnerable regions in the success factors explaining economic performance were also tested. The analysis was run for both economic activities in general and for the manufacturing sector in particular, in order to highlight the differences. Table 1 presents the synthesis of the results of the econometric exercise.
\end{abstract}

[INSERT TABLE 1 HERE] 


\subsection{Success factors and strategies in vulnerable regions}

In analyzing the economic performances of vulnerable regions, we first investigate the impact of structural factors on the overall dynamics of employment, value added, and productivity, and then the impact on industrial dynamics (Table 1). In order to highlight the characteristics of vulnerable regions, we repeated the econometric analysis run on vulnerable regions on all regions and calculated the Chow test to capture statistically significant differences between the two sets of regressions (for detailed econometric results, see Table A2-A3 of Appendix 2).

If we look at the total employment dynamics, the analysis shows that the most significant factors of total employment dynamics in vulnerable regions are:

- technological innovation;

- share of high qualified workers (corporate managers);

- structural fund expenditures.

If we consider the first two indicators as the result of two strategies, namely higher productivity increases through (technological) innovation and reconversion to higher functions, these seem to perform an important role in employment growth. Interestingly, structural funds have an important job-creating role. By contrast, a sectoral reconversion has a negative relationship with employment growth, testifying that it has a cost in terms of job losses.

The Chow test is not significant in this case (Table A2 in Appendix 2), implying that factors explaining employment growth dynamics in vulnerable regions are not statistically different from those explaining all regional employment growth in Europe. 
Interestingly, the results change drastically when we analyze total value added growth. In this case, significant structural factors are:

- technological innovation;

- $\quad$ structural funds;

- sectoral reconversion.

The first result is rather important: higher value added gains are achieved through an innovation strategy, and a sectoral reconversion exerts positive effects on value added growth. Structural funds, too, positively affect value added dynamics.

Only one factor explains value added growth in negative terms. This is the relative geographical position of regions with respect to other regions, as in the case of employment growth. This means that a region's location close to growing regions is detrimental to its value added growth; the region is more a donor than a receiver.

The Chow test is rather significant in this case (Table A2 in Appendix 2): the factors explaining value added growth dynamics in vulnerable regions are statistically different from those explaining all regional value added growth in Europe. Sectoral reconversion loses its explanatory power, while a large degree of high value functions becomes significant in explaining value added growth in all regions.

The last analysis concerns productivity growth. As expected, a sectoral reconversion strategy pays in terms of productivity gains. In this case, too, the Chow test is significant. Interestingly, no strategy or structural factor positively affects the dynamics of all European regions; the sectoral reconversion strategy has a role in productivity gains only in vulnerable regions. 
4.3. Success factors in industrial growth in vulnerable regions: differences with respect to total growth

The analysis on structural factors in vulnerable regions in Europe was repeated for industrial employment, and industrial value added over the period 1998 - 2005, and for industrial productivity growth over the period $1998-2004$ for NUTS2 regions (see econometric results in Table A3). ${ }^{11}$

We may deduce from Table 1 the differences between the structural factors of total employment growth and industrial employment growth. With regard to technological innovation, this loses its explanatory power in the case of industrial employment growth. This can be explained by the fact that in manufacturing firms the capacity to exploit technological upgrading to create new jobs is controversial: some firms adopt labour-saving innovation, others develop new jobs, having a nonsignificant sign on average.

Structural funds, which were positive for total employment growth, prove to be non-significant in explaining industrial employment growth, and regional specialization changes its impact from nonsignificant to negative. This result seems to evidence that the specialization of vulnerable regions in vulnerable sectors is detrimental to their industrial employment dynamics.

As regards the differences between industrial and total value added growth, innovation and structural funds, which were significant for total value added growth, turn out to be non-significant in explaining industrial value added growth, and regional specialization becomes positive.

An annual average industrial productivity growth over the period 1998 - 2004 was regressed on the usual structural factors. ${ }^{12}$ The main results that differ from the analysis run in the case of total 
productivity growth regard regional specialization, which is significant and positive, and spillovers of growth, which are non-significant.

Interestingly, the positive sign of regional sectoral specialization on productivity growth once again highlights that specialization in a vulnerable sector does not necessarily mean a lower economic performance: a sectoral openness to global markets, when accompanied by appropriate industrial competitive strategies, turns out to be more a challenge than a threat.

\section{Conclusions}

The aim of this work has been to analyze, over the most recent period of time, the reasons for the success within the so-called vulnerable regions, i.e. those European regions that are most exposed to globalization trends. The analysis has been run on 102 European regions identified as those regions specialized in sectors that are most open to international trade. The period of analysis is the most recent period allowed by data availability, specifically the period 1995-2005. These reasons of success have been identified through the structural elements that characterize regional economies and that result from either historical endogenous development or active industrial strategies.

The analysis yields a number of findings. First of all that specialization in vulnerable sectors is not always detrimental to economic performance. Indeed, some vulnerable regions are among the strongest European regions in terms of growth and/or value added per capita, which testifies that specialization in a vulnerable sector may offer new opportunities of growth if regions are able to implement effective reaction strategies. 
Regional performances and three possible positive reaction strategies have been identified by means of simple statistical indicators (growth of value added, of productivity and of employment; regional sectoral structure). These strategies are raising productivity through innovation in the same sector of specialization; cutting costs by changing to higher phases of the production process; and reconversion from low-value-added sectors to high-value-added ones. However, only the last two strategies appear to be implemented in a significant number of vulnerable regions.

By means of a descriptive analysis it has been possible to show that the good economic growth patterns of vulnerable regions depend on certain endogenous factors, such as the presence of high value added functions, the presence of researchers, and the policy support received.

However, not all the characteristics are identically associated with the three growth rates of value added, of employment, or of productivity. Hence, for each driver of growth, the effects of regional structure and characteristics have been investigated with a multivariate econometric investigation, generally confirming the results of the univariate descriptive analysis.

The presence of high value added functions, of best performing vulnerable sectors, and of a high expenditure of structural funds on social integration and human resources turn out to be the push factors of local economies in these regions. In particular, structural funds have a decisive role in increasing employment growth. However, this positive role cannot be related to productivity gains, and this once again highlights the job-creating value of EU policies.

Moreover, the only winning strategy with which regions can achieve higher productivity gains is sectoral reconversion at the expense of employment growth (see also GARDINER et al., 2004). In fact, sectoral reconversion always exerts a positive and significant effect on value added and productivity through a decrease in employment dynamics. 
The presence of high value functions affects employment growth, while, their effects on value added and productivity gains remain unexplained. This holds for both manufacturing activities and economic activities in general.

Productivity gains achieved through technological upgrading unexpectedly play an ambiguous role in explaining value added and employment growth dynamics: technological innovation positively impacts on total employment growth and total value added growth, but the result on productivity gains is rather unclear, with a non-significant sign of the coefficient. This result can receive several explanations linked to either the indicator used (which covers only one type of innovation) or the non-efficient use of science and technology resources ${ }^{13}$.

Globalisation is an unavoidable process for regional economies, and the best strategy for regional economies to confront it is adaptation to change (see also FONTAGNÉ and LORENZI, 2005; WAI-CHUNG YEUNG, 2009). Postponing such a strategy entails high risks for a local economy obliged to take on global competition as a latecomer with respect to its competitors, increasingly locked in old forms of production organisation, with limited complementary skills developed for an adaptation strategy, and losing in the meantime important opportunities offered by globalisation processes.

\section{ACKNOWLEDGEMENTS}

The authors are grateful to three anonymous referees for their comments. The authors are solely responsible for any errors contained in the paper. Though the work is the result of joint efforts and discussion, section 4 has been written by Antonio Affuso, sections 1 and 5 have been written by Roberta Capello and sections 2 and 3 have been written by Ugo Fratesi. 


\begin{abstract}
APPENDIX
Appendix 1: Definition and Identification of Vulnerable Regions

Vulnerable regions are defined in this work as those regions with a sectoral composition more exposed than others to external competition in a globalized world, as defined by the research teams engaged in the EU project mentioned in note 2. This definition therefore does not coincide with the EU definition of regions eligible for funding under the European Convergence objective and phasing-out system.
\end{abstract}

Our definition therefore does not imply that vulnerable regions always record negative economic performances; on the contrary, their economic growth patterns may be the result of renewed competitive strategies leading to new market opportunities.

The main problem that arises when measuring the degree of regional integration into global markets is the scarcity of data. In particular, in the absence of regional trade data, vulnerable regions are identified by means a two-step procedure which first identifies the sectors most exposed to foreign competition and then measures the regional specialization in those sectors.

The first step in our methodology for identifying vulnerable regions was the identification of vulnerable sectors. The definition of 'vulnerable sector' was based on the following statistical criteria:

- trade balance $(\mathrm{X}-\mathrm{M}) /(\mathrm{X}+\mathrm{M})$ below the European average;

- import penetration rate (M/GVA) above the European average;

- growing importation ratio or declining trade balance (1999-2006), the threshold being the average European evolution. 
Application of these criteria led to the definition of four vulnerable sectors: ${ }^{14}$

1) textiles, clothing (DB) and footwear and leather goods (DC) fit all criteria. They were grouped together because they shared the same global characteristics (low-qualified labour, similar geography, etc.) and had followed similar recent evolutions;

2) manufacturing of basic metals and fabricated metal products (DJ) is a much less open sector, but its evolution has been negative in recent years, with growing openness to extraEuropean competition and a deteriorating trade balance. However, this sector has high internal differentiation, with deterioration of the trade balance being mainly concentrated on non-ferrous metals;

3) electrical and optical equipment (DL) is a very open sector, and it has a very negative trade balance, although it has been relatively stable in recent years. Like metal industries, this sector is very heterogeneous, with very negative balances in office machinery and electronic equipments, but not in very technological segments like scientific instruments. To be noted is the growing importance of Central and Eastern Europe in this sector, even if the trade balance remains slightly positive for EU15 vis-àvis NMS;

4) miscellaneous manufacturing industries (DN) have a very negative and deteriorating trade balance. DN is by definition very heterogeneous, but faces negative evolutions in nearly all subsectors, especially furniture and miscellaneous manufacturing activities (including toyse).

The second step was identification of vulnerable regions according to their specialization in sectors particularly exposed to external competition. Vulnerable regions were defined as regions with more than one standard deviation from the average of employment or added value in the vulnerable 
sectors, taken as a whole and separately (with the exception of the very heterogeneous miscellaneous sector DN).

Appendix 2. Database and Regression Results

[INSERT TABLE A1 HERE] 
[INSERT TABLE A2 HERE] 
Notes

${ }^{1}$ Studies exist on the impact of globalization on the location of firms. See among others STORPER et al., 2002; LONGHI et al., 2003; KENNEY and FLORIDA, 2004.

${ }^{2}$ The definition of vulnerable regions comes from a joint effort of the research teams engaged in a EU project - 2007.CE.16.0.AT.028 of the European Commission - in which the lead partner was the Free University of Brussels, with the Politecnico of Milan as a partner. For the methodological aspects of the definition of vulnerable regions, see Appendix 1.

${ }^{3}$ Unlike in CAMAGNI (1991), here, in order to obtain relative values, we use the difference in the ratio between regional and European growth rates. This is because employment growth has been minimal and negative for the EU in the period considered. For small values, the two calculating methods tend to be similar.

${ }^{4}$ There exists a large body literature on the causes of outsourcing and its effects. See among others FEENSTRA and HANSON (1999), BHAGWATI et al., (2004), AMITI and WEI (2005), GROSSMAN and HELPMAN (2005), MANKIW and SWAGEL (2006) and MARIN (2006).

${ }^{5}$ There are a large number of case studies on regional restructuring in Europe: see for example CHAPMAN (2005), DUNFORD (2006), GAMBAROTTO and SOLARI (2008).

${ }^{6}$ The target of our analysis is a period of increasing globalization and economic expansion. We are still not able to provide any statistically supported hint on whether the factors of regional success in years of sustained growth might not be the same which allow regions to suffer less downturns and economic crises.

${ }^{7}$ See CLARK et al., 2004, for an analysis of the adjustment strategies of small and medium-sized firms to globalization in vulnerable regions.

${ }^{8}$ This result is not uncommon in a large and much debated literature. See among others BOLDRIN and CANOVA (2001), RODRİGUEZ-POSE and FRATESI (2004) and DALL'ERBA and LE GALLO (2008). 


\begin{abstract}
${ }^{9}$ Data were drawn from several databases: Espon, Eurostat, and European Labour Force Survey. The employment and value added data at regional (NUTS2) level have been estimated by IGEAT, a research centre of the Free University of Brussels. The authors thank IGEAT for providing these data. Full details of the data used are given in Table A1 of Appendix 2.
\end{abstract}

10 The EU Labour Force Survey contains data on the professions actually performed by the interwiewed persons. In order to approximate the presence in the region of high-value added functions, we hence use the regional share of people working as managers, excluding the public sector. Since we do not have any data on wages, we are not able to know if these high-level jobs are highly paid, nor we are able to discuss about the relationship between the earnings distribution and the productivity gaps. For a recent analysis of the effects of income polarization on regional growth, see EZCURRA (2009).

${ }^{11}$ The period of analysis is chosen according to data availability.

12 This is the only case in which the dummy on agglomeration economies interferes with the other explanatory variables. For this reason, it has not been inserted.

${ }^{13}$ For a discussion on the possible available indicators of innovation see SMITH (2006), while on the potential discrepancy between the presence of innovative assets and the actual capability of a region to use them to grow, see BILBAO-OSORIO and RODRIGUEZ-POSE (2004), CRESCENZI (2005) and CRESCENZI and RODRIGUEZ-POSE (2009).

${ }^{14}$ For detailed description of the methodology and the database, see project 2007.CE.16.0.AT.028 of the European Commission, available on the EU website. 


\section{References}

ABRAHAM K. G. and TAYLOR S. K. (1996), Firms' use of outside contractors: Theory and evidence, Journal of Labor Economics, 14, 3: 394-424.

AMITI M. and WEI S. J. (2005), Fear of service outsourcing: is it justified?, Economic Policy 20, 42: 308-347.

BALDWIN R. (2006), Globalisation: the great unbundling(s), Paper for the Finnish Prime Minister's Office, Economic Council of Finland as part of EU Presidency.

BALDWIN R. E., FRANCOIS J. F., PORTES R., RODRIK D. and SZEKELY I. P. (1997), The Costs and Benefits of Eastern Enlargement: The Impact on the EU and Central Europe, Economic Policy, Vol. 12, n. 24, pp. 125-176

BHAGWATI J., PANAGARIYA A. and SRINIVASAN, T. N. (2004), 'The muddles of outsourcing', Journal of Economic Perspectives 18, 4: 93-114.

BILBAO-OSORIO and RODRIGUEZ-POSE A. (2004), From R\&D to Innovation and Economic Growth in the EU, Growth and Change, vol. 35, no. 4, pp. 434-455.

BOLDRIN M. and CANOVA F. (2001), Inequality and convergence in Europe's regions: reconsidering European regional policies. Economic Policy 32 207-253. 
BURDA M., BEAN C. and SVEJNAR J. (1993), Unemployment, Labour Markets and Structural Change in Eastern Europe, Economic Policy, Vol. 8, n. 16, pp. 102-137

CAMAGNI R. (1991), Regional Deindustrialization and Revitalization Processes in Italy in RODWIN L. and SAZANAMI, H. (eds.) Industrial Change and Regional Economic Transformation, Harper Collins, London, pp. 137-167.

CAMAGNI R., (2001), Policies for spatial development, in OECD Territorial Outlook, Paris, 147169.

CAMAGNI R. (2002), On the concept of territorial competitiveness: sound or misleading?, Urban Studies, n. 13, pp. 2395-2412.

CAPELLO R. (2009), Spatial Spillovers and Regional Growth, European Planning Studies, Vol. 17, n. 5, pp. 639-658

CHAPMAN K. (2005), From 'Growth Centre' to 'Cluster': Restructuring, Regional Development, and the Teesside Chemical Industry, Environment and Planning A, v. 37, iss. 4, pp. 597-615.

CLARK G. L., PALASKAS T., TRACEY P. and TSAMPRA, M. (2004), Globalisation and Competitive Strategy in Europe's Vulnerable Regions: Firm, Industry and Country Effects in LabourIntensive Industries, Regional Studies, Vol. 38, n. 9, pp. 1085-1100.

CRESCENZI R. (2005), Innovation and Growth in the Enlarged Europe: the Role of Local Innovative Capabilities Peripherality and Education, Growth and Change, Vol. 36, No. 4, pp. 471-507. 
CRESCENZI R. and RODRİGUEZ-POSE A. (2009), Systems of innovation and regional growth in the EU: endogenous vs external innovative efforts and socioeconomic conditions. In: FRATESI U, SENN L (eds.) Growth and innovation of competitive regions: the role of internal and external connections. Springer, Berlin.

CUADRADO-ROURA J. R., MANCHA-NAVARRO T. and GARRIDO-YSERTE R. (2000), Regional productivity patterns in Europe: An alternative approach The Annals of Regional Science, Vol. 34, n. 3, pp. 365-384

DALL'ERBA S. and LE GALLO J. (2008), Regional convergence and the impact of European structural funds over 1989-1999: A spatial econometric analysis, Papers in Regional Science; 87-2, 219-244.

DUNFORD M. (2003), Theorising regional economic performance and the changing territorial division of labour, Regional Studies, v. 37, pp. 839-854.

DUNFORD M. (2006), Industrial Districts, Magic Circles, and the Restructuring of the Italian Textiles and Clothing Chain, Economic Geography, January 2006, v. 82, iss. 1, pp. 27-59.

EZCURRA R. (2009), Does Income Polarization Affect Economic Growth? The Case of the European Regions, Regional Studies, Vol.43, pp. 267-285

FEENSTRA R. C. (1998), Integration of Trade and Disintegration of Production in the Global Economy, Journal of Economic Perspectives, 12(4): 31-50. 
FEENSTRA R. C. and HANSON G. (1999), 'The impact of outsourcing and high-technology capital on wages: Estimates for the United States, 1979-1990', Quarterly Journal of Economics 114, 3: 907940.

FONTAGNE L. and LORENZI J-H. (2005), Désindustrialisation, Délocalisations, La Documentation Française, Paris

GAMBAROTTO F. and SOLARI S. (2008), Restructuring of local production systems: two Italian case studies about responses to globalisation, Revue d'Economie Regionale et Urbaine, 2008, iss. 1, pp. 3-20.

GARDINER B., MARTINER, R. and TYLER P., (2004), Competitiveness, Productivity and Economic Growth across the European Regions, Regional Studies Vol. 38, n. 9, pp. 1045-1067.

GIULIANI E., RABELLOTTI R., and VAN DIJK M.P. (2005), (eds.) Clusters Facing Competition: The Importance of External Linkages, Ashgate, Aldershot.

GROSSMAN G. M. and HELPMAN E. (2005), 'Outsourcing in a global economy', Review of Economic Studies 72, 1: 135-159.

GROSSMAN G.M., ROSSI-HANSBERG E. (2008), Trading Tasks: A Simple Theory of Offshoring, American Economic Review, 98-5, 1978-1997.

HUMPREY J. and SCHMIDZ A. (2002), How does insertion in global value chains affect upgrading in industrial clusters?, Regional Studies, Vol.36, pp.1017-1027. 


\begin{abstract}
KAMARIANAKIS Y. and LE GALLO J. (2003), The evolution of regional productivity disparities in the European Union, 1975-2000, mimeo, Department of Economics, University of Crete.
\end{abstract}

KENNEY M. and FLORIDA R. (2004), Locating global advantage: industry dynamics in the international economy, Stanford University Press, Stanford Ca., Preface.

LONGHI S., NIJKAMP P. and TRAISTARU I. (2003), Economic Integration and Manufacturing Location in EU Accession Countries, Tinbergen Institute Discussion Paper, TI 2003-093/3.

MANKIW G. N., and SWAGEL P. (2006), 'The politics and economics of offshore outsourcing', Journal of Monetary Economics 53, 5: 1027-1056.

MARIN D. (2006), A new international division of labor in Europe: Outsourcing and offshoring to Eastern Europe, Journal of the European Economic Association 4, 2-3: 612-622.

OECD (2007), Globalisation and Regional Economies, Paris, ch. 1 and 2.

RODRİGUEZ-POSE A. and FRATESI U. (2004), Between development and social policies: the impact of European Structural Funds in Objective 1 regions, Regional Studies, Vol.38, No 1, 2004, pp. $97-113$.

SMITH K. (2006), Measuring Innovation, in Fagerberg, J., Mowerey, D. C. Nelson, R.R., The Oxford Handbook of Innovation, Oxford University Press.

STORPER M. CHEN Y. and DE PAOLIS F. (2002), Trade and the Location of Industries in the OECD and European Union, Journal of Economic Geography, n. 2, pp. 73-107. 
UNCTAD (various years), World Investment Report.

WAI-CHUNG YEUNG H. (2009), Situating Regional Development in the Competitive Dynamics of Global Production Networks: An East-Asian Perspective, Regional Studies, Vol. 43, n. 3, pp. 325 351

World Bank (various years), World Development Report. 
Figure 1 - The European vulnerable regions

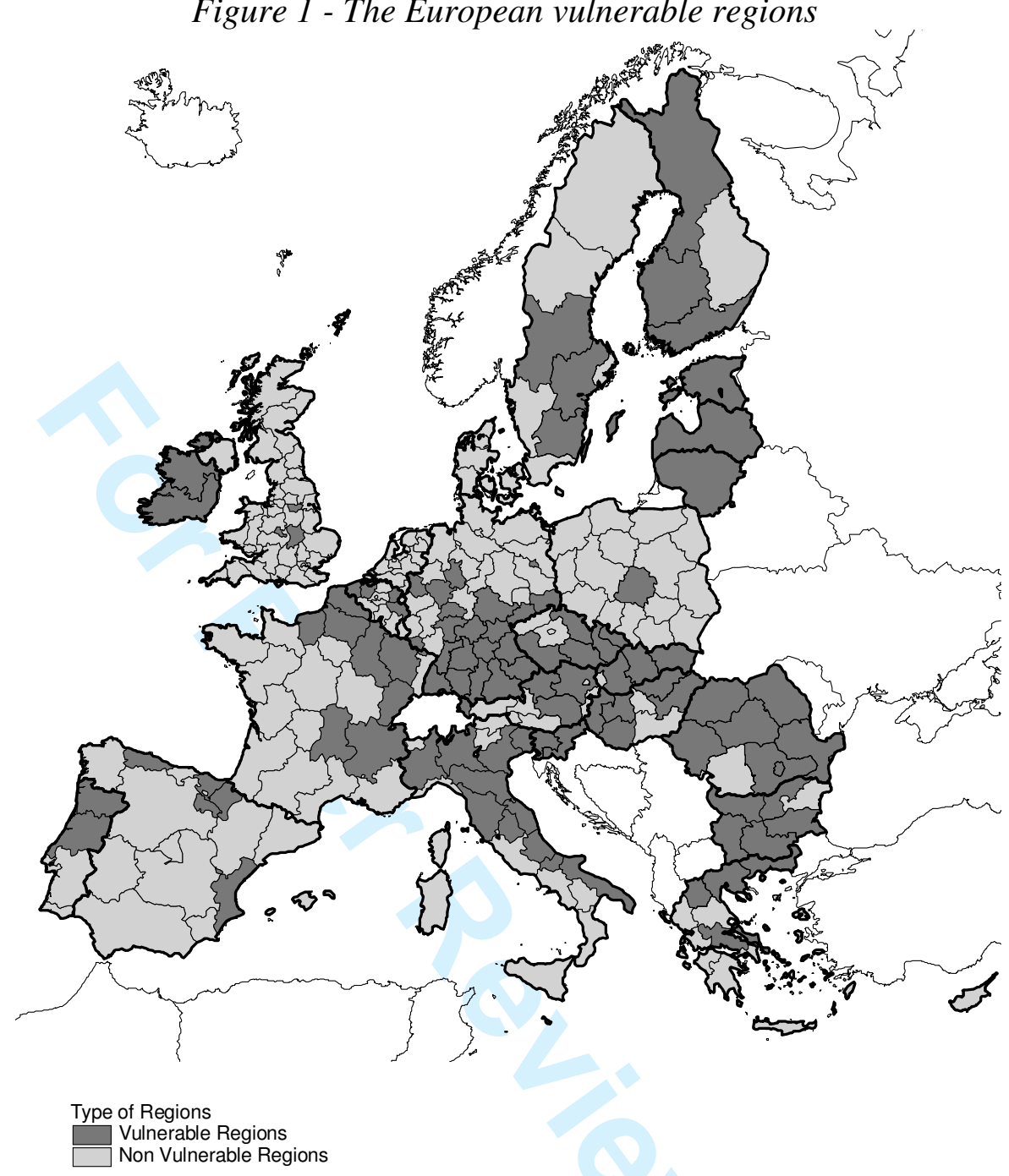

Source: IGEAT regional/sectoral employment matrix 


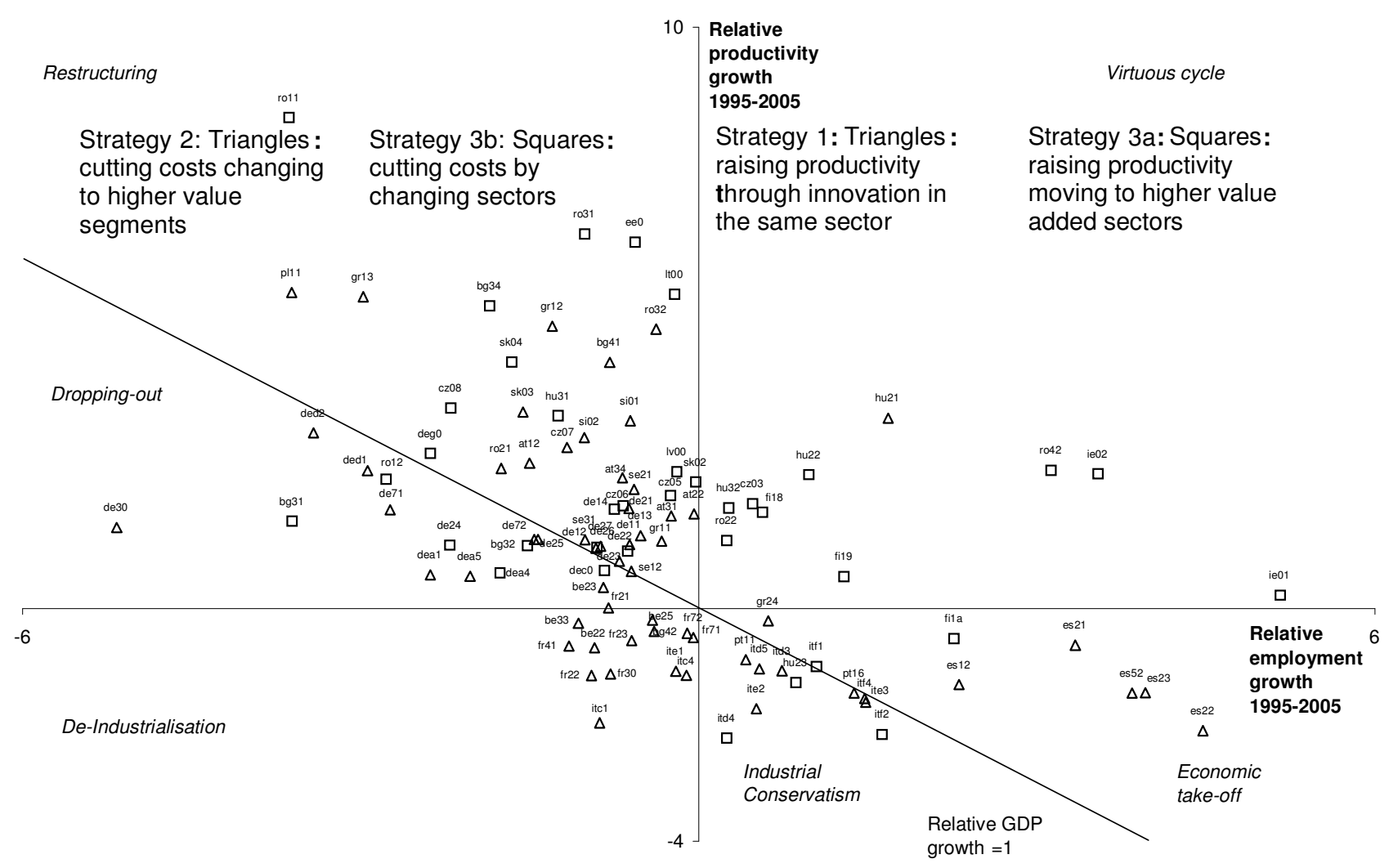

Legend: squares= higher- than-average sectoral change; triangles: lower-than-average sectoral change. Source: our elaborations on Eurostat data 
Figure 3 - The growth patterns followed by European vulnerable regions

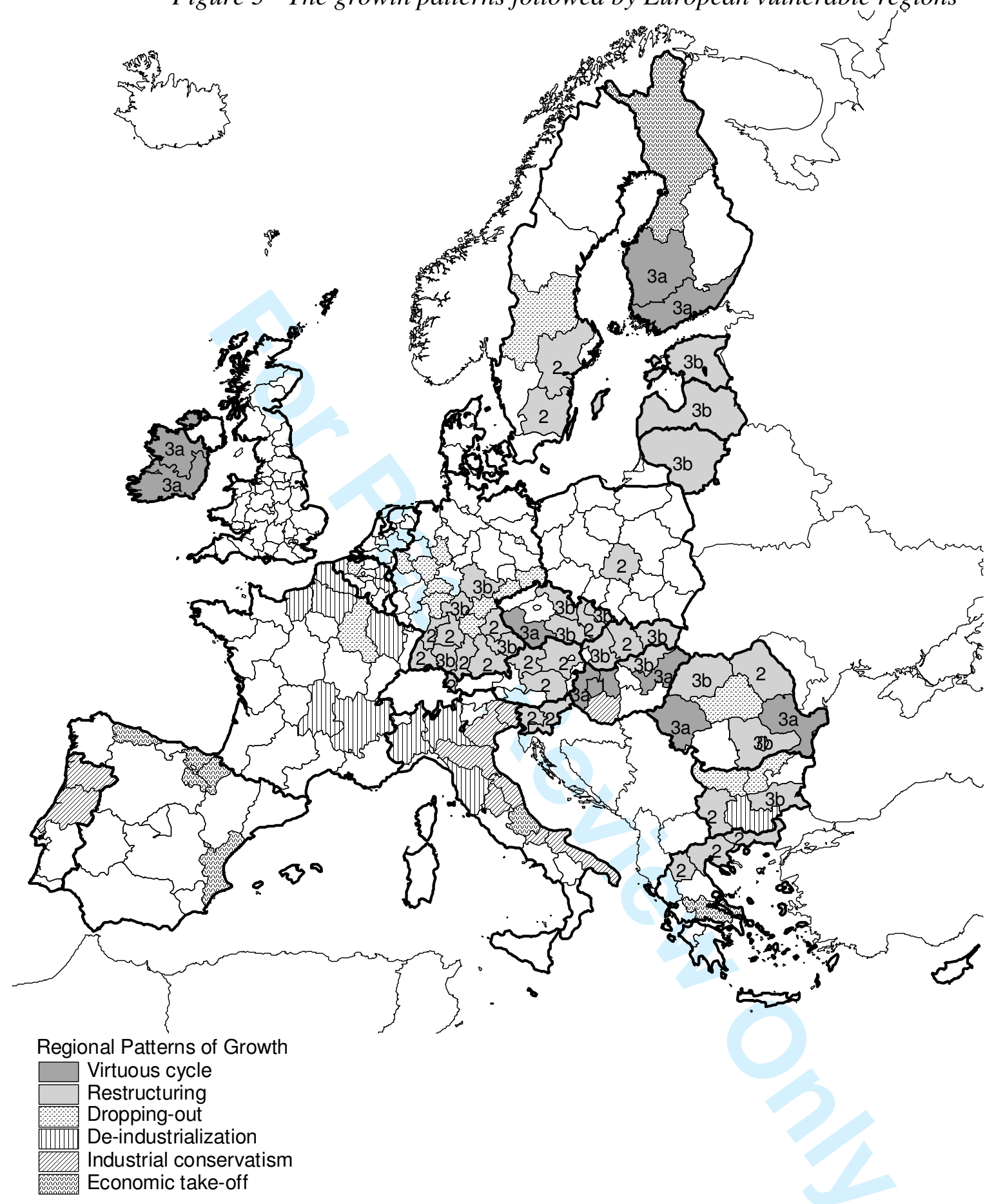

Source: our elaborations from Eurostat data 
Figure 4 - Structural features associated to each industrial growth pattern

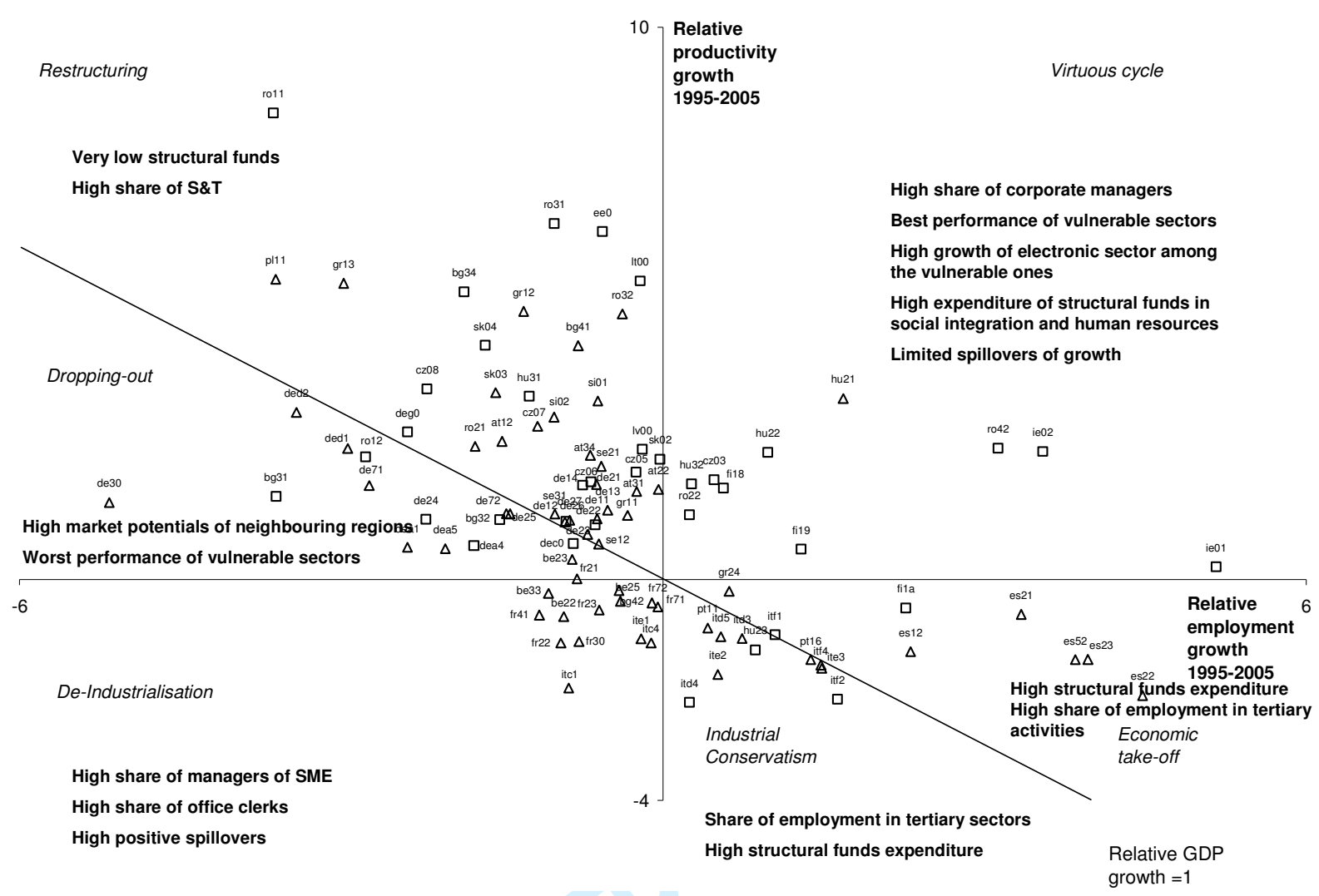

Source: our elaborations from Eurostat data 
Figure 5 - Description of vulnerable regions according to their growth pattern typologies

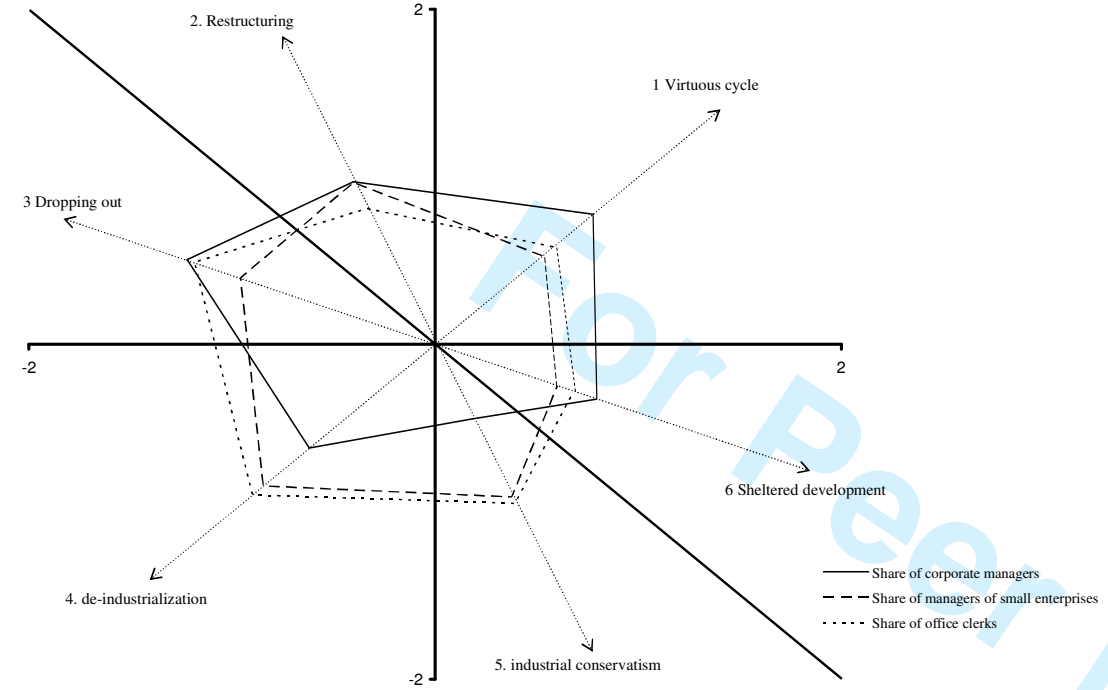

A Professions (source: Labour Force Survey)

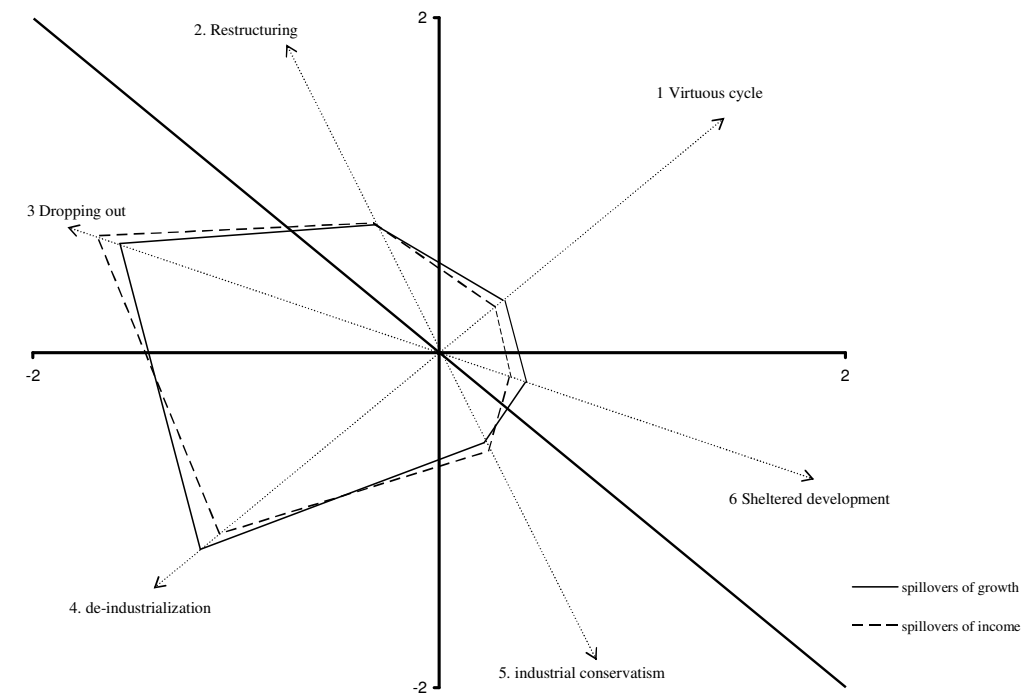

C Growth spillovers and market potential (Source: our elaboration on Eurostat data)

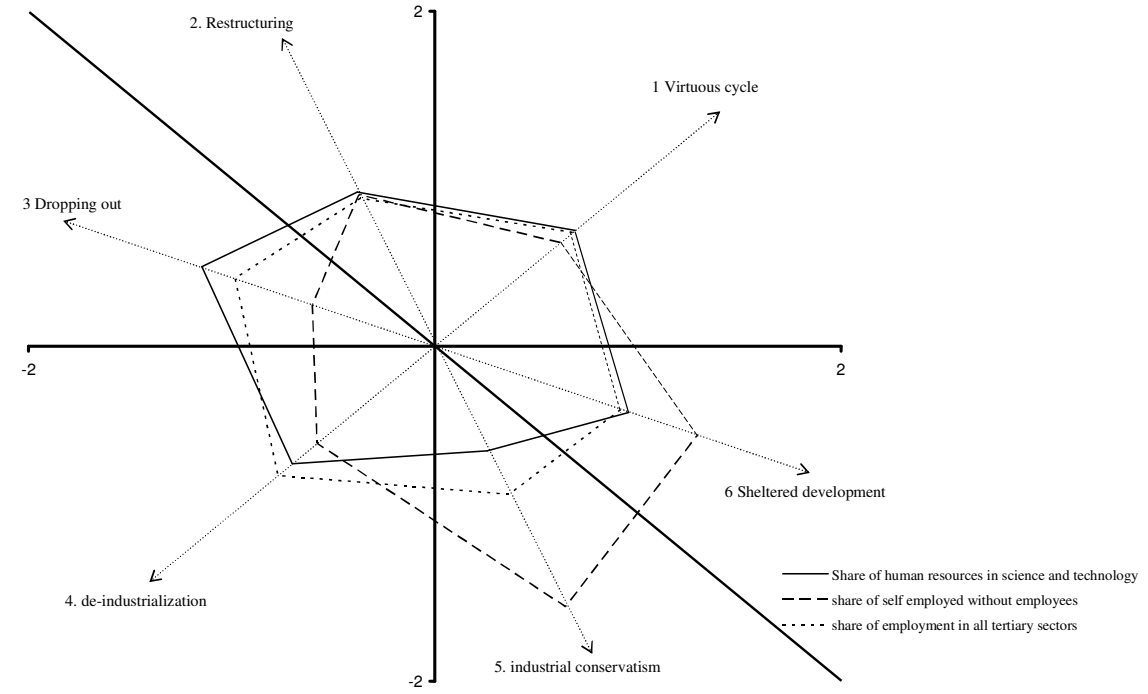

B Human resources in science and technology, self employment and tertiary sector (Source: Eurostat and IGEAT matrix)

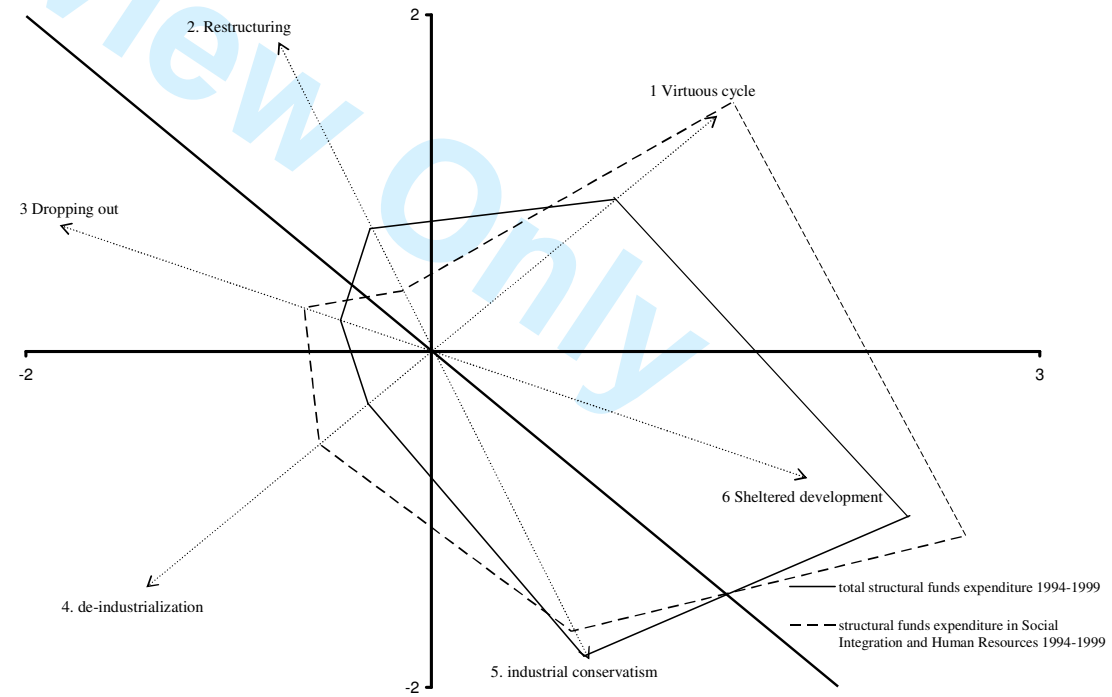

D Structural funds (Source: ESPON database) 
Table 1 - Success factors in the economic and industrial performances of European vulnerable regions

\begin{tabular}{|c|c|c|c|c|}
\hline & & Positive effects & Negative effects & Non-significant \\
\hline \multirow[t]{7}{*}{$\Delta$ total employment } & - technological innovation ; & $X$ & & \\
\hline & - share of high-skilled workers; & $\mathrm{X}$ & & \\
\hline & - structural fund. & $\mathrm{X}$ & & \\
\hline & - regional specialization; & & & $\mathrm{X}$ \\
\hline & - growth spillover. & & $\mathrm{X}$ & \\
\hline & - sectoral reconversion & & $\mathrm{X}$ & \\
\hline & - agglomeration economies & & & $X$ \\
\hline \multirow[t]{7}{*}{$\Delta$ total value added } & - technological innovation; & $\mathrm{X}$ & & \\
\hline & - share of high-skilled workers; & & & $\mathrm{X}$ \\
\hline & - structural fund. & $\mathrm{X}$ & & \\
\hline & - regional specialization; & & & $\mathrm{X}$ \\
\hline & - growth spillover. & & $\mathrm{X}$ & \\
\hline & -sectoral reconversion & $\mathrm{X}$ & & \\
\hline & - agglomeration economies & & & $\mathrm{X}$ \\
\hline \multirow[t]{7}{*}{$\Delta$ total productivity } & - technological innovation; & & & $\mathrm{X}$ \\
\hline & - share of high-skilled workers; & & & $\mathrm{X}$ \\
\hline & - structural fund. & & & $\mathrm{X}$ \\
\hline & - regional specialization; & & & $\mathrm{X}$ \\
\hline & - growth spillover. & & $\mathrm{X}$ & \\
\hline & -sectoral reconversion & $\mathrm{X}$ & & \\
\hline & - agglomeration economies & & $\mathrm{X}$ & \\
\hline \multirow{7}{*}{$\begin{array}{l}\Delta \text { industrial } \\
\text { employment }\end{array}$} & - technological innovation; & & & $\mathrm{X}$ \\
\hline & - share of high- skilledworkers; & $\mathrm{X}$ & & \\
\hline & - structural fund. & & & $\mathrm{X}$ \\
\hline & - regional specialization; & & $\mathrm{X}$ & \\
\hline & - growth spillover. &  & $\mathrm{X}$ & \\
\hline & -sectoral reconversion & $\sqrt{3}$ & $\mathrm{X}$ & \\
\hline & - agglomeration economies & + & & $\mathrm{X}$ \\
\hline \multirow{7}{*}{$\begin{array}{l}\Delta \text { industrial value } \\
\text { added }\end{array}$} & - technological innovation; & V & & $\mathrm{X}$ \\
\hline & - share of high-skilled workers; & & & $\mathrm{X}$ \\
\hline & - structural fund. & & & $\mathrm{X}$ \\
\hline & - regional specialization; & $\mathrm{X}$ & & \\
\hline & - growth spillover. & & $\mathrm{X}$ & \\
\hline & -sectoral reconversion & $\mathrm{X}$ & & \\
\hline & - agglomeration economies & & & $\mathrm{X}$ \\
\hline \multirow{6}{*}{$\begin{array}{l}\Delta \text { industrial } \\
\text { productivity }\end{array}$} & - technological innovation; & & & $\mathrm{X}$ \\
\hline & - share of high-skilled workers; & & & $\mathrm{X}$ \\
\hline & - structural fund. & & & $\mathrm{X}$ \\
\hline & - regional specialization; & $\mathrm{X}$ & & \\
\hline & - growth spillover. & & & $\mathrm{X}$ \\
\hline & - sectoral reconversion & $\mathrm{X}$ & & \\
\hline
\end{tabular}

Source: results from regression analyses in annex 2 
Table A1. Regional economic data and variables

Indicators Definition Source of raw data

Regional GDP in real terms at NUTS2 level in the period 1995-2005, computed from the nominal one, using national GDP deflators.

Regional employment growth of the tertiary and manufacturing sectors.

Regional employment growth of the tertiary and manufacturing sectors, computed from absolute employment in the years 1995 to 2005 .

Regional employment by NACE 2 Regional NUTS2 employment for each sector NACE 2 sector for the year 2002

Location quotient by NACE 2 sector

Regional share of employment or value added by sector for the years 1995 and 2002 at NUTS2 level.

Regional value added by NACE 2 Regional value added for each NACE 2 sector sector for the years 1995 and 2002

Regional employment by function (ISCO)

Regional employment by function at ISCO

2 digit classification at Nuts 2 level.

Regional share of human resources in $S \& T$

Share of people working in S\&T on population at NUTS 2 in the year 2000

Per capita structural funds

Total structural funds expenditure / population in the period 1994-1999. Also divided into 5 types of expenditure.

Agglomerated regions

With a city of $>300,000$ inhabitants and a population density $>300$ inhabitants / km sq. or a population density $150-300$ inhabitants / km sq.
Eurostat

Eurostat

IGEAT matrix*

IGEAT matrix

IGEAT matrix

European Labour Force Survey

Eurostat

Espon database

Espon database

*The employment and value added data at regional (NUTS2) level have been estimated by IGEAT, a research centre of the Free University of Brussels. The authors thank IGEAT for providing these data 
Table A2. Success factors in European regional economic growth: results from regression analyses

\begin{tabular}{|c|c|c|c|c|c|c|c|c|c|}
\hline \multirow{3}{*}{$\begin{array}{l}\text { Economic } \\
\text { performance } \\
\text { measures }\end{array}$} & \multicolumn{3}{|c|}{$\Delta$ total employment } & \multicolumn{3}{|c|}{$\Delta$ total value added } & \multicolumn{3}{|c|}{$\Delta$ total productivity } \\
\hline & $\begin{array}{l}\text { All } \\
\text { sample }\end{array}$ & $\begin{array}{l}\text { Vulnerable } \\
\text { regions }\end{array}$ & $\begin{array}{l}\text { Non- } \\
\text { vuln. } \\
\text { regions }\end{array}$ & $\begin{array}{l}\text { All } \\
\text { sample }\end{array}$ & $\begin{array}{l}\text { Vulnerable } \\
\text { regions }\end{array}$ & $\begin{array}{l}\text { Non - } \\
\text { vuln. } \\
\text { regionss }\end{array}$ & $\begin{array}{l}\text { All } \\
\text { sample }\end{array}$ & $\begin{array}{l}\text { Vulnerable } \\
\text { regions }\end{array}$ & $\begin{array}{l}\text { Non-vuln. } \\
\text { regions }\end{array}$ \\
\hline & & & & & & & & & \\
\hline Innovation & $\begin{array}{l}1.338 * \\
(0.000)\end{array}$ & $\begin{array}{l}.748 * * \\
(0.023)\end{array}$ & $\begin{array}{l}1.899 * \\
(0.001)\end{array}$ & $\begin{array}{l}.520 * \\
(0.008)\end{array}$ & $\begin{array}{l}1.059 * \\
(0.008)\end{array}$ & $\begin{array}{l}.474 * * \\
(0.044)\end{array}$ & $\begin{array}{l}-.762 * * * \\
(0.075)\end{array}$ & $\begin{array}{l}.010 \\
(0.983)\end{array}$ & $\begin{array}{l}-1.604 * * \\
(0.018)\end{array}$ \\
\hline $\begin{array}{l}\text { High v.a. } \\
\text { functions }\end{array}$ & $\begin{array}{l}784 * \\
(0.005)\end{array}$ & $\begin{array}{l}.746 * * \\
(0.031)\end{array}$ & $\begin{array}{l}.893 * * * \\
(0.056)\end{array}$ & $\begin{array}{l}.464 * \\
(0.007)\end{array}$ & $\begin{array}{l}.634 \\
(0.124)\end{array}$ & $\begin{array}{l}.380 * * \\
(0.045)\end{array}$ & $\begin{array}{l}-.016 \\
(0.973)\end{array}$ & $\begin{array}{l}-.379 \\
(0.629)\end{array}$ & $\begin{array}{l}-.474 \\
(0.475)\end{array}$ \\
\hline $\begin{array}{l}\text { Regional } \\
\text { specialization }\end{array}$ & $\begin{array}{l}.385 \\
(0.274)\end{array}$ & $\begin{array}{l}-.432 \\
(0.112)\end{array}$ & $\begin{array}{l}.802 \\
(0.159)\end{array}$ & $\begin{array}{l}.154 \\
(0.647)\end{array}$ & $\begin{array}{l}-.816 \\
(0.198)\end{array}$ & $\begin{array}{l}.339 \\
(0.400)\end{array}$ & $\begin{array}{l}-.051 \\
(0.927)\end{array}$ & $\begin{array}{l}-.073 \\
(0.938)\end{array}$ & $\begin{array}{l}.255 \\
(0.739)\end{array}$ \\
\hline $\begin{array}{l}\text { Sectoral } \\
\text { reconversion }\end{array}$ & $\begin{array}{l}-.718 * \\
(0.003)\end{array}$ & $\begin{array}{l}-.937 * \\
(0.004)\end{array}$ & $\begin{array}{l}-.640 * * * \\
(0.083)\end{array}$ & $\begin{array}{l}-.166 \\
(0.252)\end{array}$ & $\begin{array}{l}.579 * * \\
(0.044)\end{array}$ & $\begin{array}{l}-.441 * \\
(0.005)\end{array}$ & $\begin{array}{l}.469 \\
(0.133)\end{array}$ & $\begin{array}{l}1.231 * * \\
(0.015)\end{array}$ & $\begin{array}{l}-.043 \\
(0.910)\end{array}$ \\
\hline $\begin{array}{l}\text { Agglomeration } \\
\text { economies }\end{array}$ & $\begin{array}{l}-.056 \\
(0.320)\end{array}$ & $\begin{array}{l}.005 \\
(0.902)\end{array}$ & $\begin{array}{l}-.122 \\
(0.205)\end{array}$ & $\begin{array}{l}-.111 * * \\
(0.012)\end{array}$ & $\begin{array}{l}-.098 \\
(0.198)\end{array}$ & $\begin{array}{l}-.057 \\
(0.299)\end{array}$ & $\begin{array}{l}-.070 \\
(0.386)\end{array}$ & $\begin{array}{l}-.156 * * \\
(0.036)\end{array}$ & $\begin{array}{l}.086 \\
(0.515)\end{array}$ \\
\hline $\begin{array}{l}\text { Spillovers of } \\
\text { growth }\end{array}$ & $\begin{array}{l}-.141 * \\
(0.008)\end{array}$ & $\begin{array}{l}-.260 * * \\
(0.025)\end{array}$ & $\begin{array}{l}-.190 * * \\
(0.026)\end{array}$ & $\begin{array}{l}-.003 \\
(0.645)\end{array}$ & $\begin{array}{l}-.591 * \\
(0.000)\end{array}$ & $\begin{array}{l}-.003 \\
(0.769)\end{array}$ & $\begin{array}{l}-.100 \\
(0.364)\end{array}$ & $\begin{array}{l}-.366 * * \\
(0.077)\end{array}$ & $\begin{array}{l}.056 \\
(0.629)\end{array}$ \\
\hline $\begin{array}{l}\text { Structural } \\
\text { funds } \\
\text { expenditures }\end{array}$ & $\begin{array}{l}.129 * \\
(0.000)\end{array}$ & $\begin{array}{l}.095 * \\
(0.000)\end{array}$ & $\begin{array}{l}.155 * * \\
(0.014)\end{array}$ & $\begin{array}{l}.057 * * \\
\vdots(0.012)\end{array}$ & $\begin{array}{l}.074 * \\
(0.006)\end{array}$ & $\begin{array}{l}.040 * \\
(0.005)\end{array}$ & $\begin{array}{l}-.066 \\
(0.27)\end{array}$ & $\begin{array}{l}.002 \\
(0.959)\end{array}$ & $\begin{array}{l}-.107 * * \\
(0.040)\end{array}$ \\
\hline R-square & 0.28 & 0.40 & 0.28 & 0.16 & 0.39 & 0.16 & 0.08 & 0.23 & 0.10 \\
\hline $\begin{array}{l}\text { N. of } \\
\text { observations }\end{array}$ & 184 & 82 & 102 & 227 & 88 & 139 & 171 & 78 & 93 \\
\hline Chow test & 1.029 & & & $4.703 *$ & & & $1.693 * * *$ & & \\
\hline
\end{tabular}

Legend:

* Significant at $1 \%$ level

** Significant at $5 \%$ level

*** Significant at $10 \%$ level

Coefficients represent the marginal effects of a $1 \%$ increase in each independent variable on the dependent variable.

Estimates have been estimated with "robust" standard errors and with the constant term. 
Table A3. Success factors in European regional industrial growth: results from regression analysis



Legend:

* Significant at $1 \%$ level

** Significant at $5 \%$ level

*** Significant at $10 \%$ level

Coefficients represent the marginal effects of a $1 \%$ increase in each independent variable on the dependent variable.

Estimates have been estimated with "robust" standard errors and with the constant term.

+ This is the only case in which the dummy on agglomeration economies shows multi-collinearity with the other explanatory variables. For this reason, it has not been inserted. 